\title{
The Scope and Limitations of Brief Interventions for Remedial Education: An Experimental Approach in a Numeracy Case
}

\author{
Conrado Ruiz-Hernández, Alma Delia Lupercio Lozano, Thalía Ameyatzin Bernal González \\ Unit of Interdisciplinary Research of Health and Education Sciences in FES-Iztacala at the National Autonomous University of Mexico \\ (UNAM-Iztacala), Tlalnepantla, State of Mexico, Mexico
}

\section{Email address:}

cruiz@campus.iztacala.unam.mx (C. Ruiz-Hernández), luperal11@yahoo.com.mx (A. D. Lupercio), bioamethal@gmail.com (Th. A. Bernal)

\section{To cite this article:}

Conrado Ruiz-Hernández, Alma Delia Lupercio Lozano, Thalía Ameyatzin Bernal González. The Scope and Limitations of Brief Interventions for Remedial Education: An Experimental Approach in a Numeracy Case. International Journal of Secondary Education. Vol. 3, No. 4, 2015, pp. 32-36. doi: 10.11648/j.ijsedu.20150304.12

\begin{abstract}
In the practice of teaching, there are some lessons that students never fully learn, so developing the right teaching strategy is vital and involves more than just implementing isolated and unrelated educational intervention proposals. The improvement of world educational systems must be truly global and not limited to just those countries experiencing shortcomings as they try to catch up with the leaders in international OECD evaluations. Instead, we need educational advancement on a global basis and these educational standards must be well measured. In this endeavor, linguistics, mathematics, science and social studies all have strategic value. We report the outcome of an experimental design as a control and on three remedial intervention strategies in the specific field of numeracy.
\end{abstract}

Keywords: Remedial Education, Numeral Literacy, Numeracy, PISA, PIIAC

\section{Introduction}

Students of basic education have a huge knowledge gap, particularly in mathematical and language topics, which in turn affects performance in other fields of knowledge $[2,3]$. This may be due to the intrinsic complexity of the subject, the students' lack of an adequate basis for the understanding of new lessons, bad teaching design and a lack of teacher training, among other causes. A negative outcome may be explained by the existence of one or several of these causes. The search for the solution to specific learning problems requires the identification of and analysis of possible causes. We must also rely on the experience and skill of the teaching corps. This is best achieved by always starting from an objective basis without positing miracle solutions inspired by first thoughts or demagogy.

For example, we cannot provide high level computer technology to schools without first considering the proper teacher training in how to use the equipment or other factors such as the availability of electric energy and decent classrooms. As reported herein, this weakness was very apparent in the unfortunate Mexican program called "enciclomedia" $[5,7]$. The international experience shows that well planned educational reforms with a solid medium or long term-oriented background better achieve educational goals than those based on improvisation and voluntarism only $[14,24]$.

\section{A Pocket Educational Experiment}

Basic education ends in the third year of junior high school. A well known fact is that the Organization for Economic Cooperation and Development (OECD) evaluations of school performance show very uneven results among the countries taking part. Some countries will always appear to be at an advantage for socioeconomic reasons, level of democracy or factors relating to cultural or computer science development $[9,27]$. According to the standardized test applied by INEE, ENLACE, in $2010,53 \%$ of secondary school students had an insufficient math skills and another $34.7 \%$ just reached basic skills in math [9]. In other way, according to the PISA 2009 test, $51 \%$ of 15 -year-old students in Mexico's educational system performed below level 2 in mathematics $(55 \%$ in PISA 2012), and just $5 \%$ ranked in the highest level $[16,18]$. In order to prove what can be achieved with certain educational interventions aimed at correcting or repairing 
deficient or non-existent learning in a wide range of fields, we organized an experimental design with third year pupils in a secondary school. They were randomly selected through reassortments of the entire set- in order to form 40 individual groups per treatment who would be mentioned below. The groups had an equal number of boys and girls. This research was carried out in a Mexican school. However, we do think that the analysis of our observation is applicable on a global level.

\section{Objectives}

1) To define a set of remedial educational strategies. These must be representative of normal teaching practice.

2) To elaborate and apply a testable experimental design, choosing strategies with a specific mathematical learning example.

\section{Hypothesis}

"Normal, isolated and unattached remedial interventions are usually inefficient and give poor results".

\section{Method}

The specific topic chosen was the ability of students to identify the parts of a polynomial, as well as the students' skill in performing arithmetic operations in a buy-and-sell negotiation (this seems to be an intrinsic ability that can be learned without attending school) [13]. The participants were 160 regular third year students from a public secondary school. The four treatments were randomly assigned to a group evenly divided by gender. The average age was between 14 and 15 years old.

\section{Questions Applied and Design Instrumentation}

A questionnaire examining basic arithmetic knowledge (see table 1) consisted in twelve questions, one of which was directed at the experimental variable (the addition of a polynomial).

- Simple operations implied in a commercial transaction: a girl bought a $\$ 2.00$ lollypop and 3 chocolates that cost $\$ 4.00$ each. How much did she spend?

- Perform the addition of a polynomial: $3.2+4.4 \times 2$.

In the first question, the answer is 14 pesos (Mexican monetary unit) and in the second, 12. Of these two questions, the second one is reported as a genuine school learning problem [1]. The reason is that students don't usually learn to distinguish those terms in an equation which are independent counts or numeric values by themselves from those which are separated by an addition or subtraction sign. Usually, they are two similar arithmetic operations, both consisting of two terms. However, one of them is made in the field of real life and the other one is an abstraction $[11,23]$.
Four treatments were applied simultaneously:

I. A control group made up of regular students. A diagnosis was made in this group regarding adequate or deficient learning for a specific school topic. The entire questionnaire was presented unchanged in its original complete form.

II. The questionnaire of this group (II) was presented with modifications, a brief explanation of the terms in a polynomial: "Remember that in this operation, independent calculations or numeric values by themselves known as terms, are separated by an addition [+] or subtraction [-] sign". They were asked to pay attention as they read the question, before attempting to solve it. These could also represent the usual talk given to encourage the students before sitting an examination.

III. In the case of group III, the term identification was made easy, by separating them with parenthesis: 3.2 $+(4.4 \times 2)$.

IV. To a fourth group of students, was planned a class of 90 minutes, where the analogies between a word separated in syllables and the segregation of independent quantities or numerical algebraic values by themselves, were explained. Also an explication of terms in a polynomial was provided; in other words, a serious and well-planned educational intervention was given. In this way a series of terms such as: $2 / 5,3^{2}, 25, \sqrt{16}, 3 \times 4,32 / 2^{3}$ were explained. Then, the entire questionnaire was presented unchanged in its original complete form.

Table 1. Contextual questionnaire applied.

\begin{tabular}{lll}
\hline Questions & Answers \\
\hline 1$)^{*}$ & $3968+(?)=4987$ & 1019 \\
$2)^{*}$ & $(?) \times 5=2160$ & 432 \\
$3)^{*}$ & $43.50+(?)=65.92$ & 22.42 \\
$4)^{*}$ & $(?) \times 0.5=234.0$ & 468 \\
$5)$ & Power $2^{5}$ & 32 \\
$6)$ & Is $\sqrt{9}$ bigger, smaller or equal to 3? & equal \\
$7)$ & If 4 meat sandwiches cost 60 pesos, what is the & 45 pesos \\
$8)$ & $\quad$ price of three? & 92.5 \\
& Look at these numbers: $2.8,2.71$ and & \\
$9)^{* *}$ & 2.798: Which is the biggest? & 2.8 \\
& Which is the smallest? & 2.71 \\
$10)$ & How much is half of $1 / 2 ?$ & $1 / 4$ \\
\hline
\end{tabular}

* In this questionnaire, operations are shown in a vertical form (as typical drills are performed), however, solutions are not literal. They are exhibited in a reverse form. Every calculation was made without using a pocket calculator.

** In this question a point is given only if the student supplies two right answers.

\section{Results}

The more successful strategies (see figure 1), those attaining their goals, were those applied to group III (supply casual help) and IV (re-teach by means of an intensive class). The results of strategy III deserve specific analysis. Even though an important improvement was attained in relation to 
other treatments (group I control) and group II (the supplying of 'light' information to students), this does not mean that the desired structured learning was encouraging. It was made easier, although this group failed. To apply the alpha Cronbach coefficient or the Spermann coefficient, questionnaires must be made with questions having a difficulty index between 0.4 and 0.6 . The polynomial addition without brackets goes beyond zero to 0.525 (intermediate difficulty). If the polynomial hadn't had brackets, the score would have been similar to that obtained in group I and group II (zero or nearly zero). In the second group, just two students gave the right answer and we proved by means of subsequent questions that the reminder did help and this was new knowledge for them; indicating that was useful for them if the short intervention. One of them obtained nine right answers in the mathematical contextual questionnaire. He only made a mistake on the exponent $\left(2^{5}\right)$, the other student left some questions blank and did not make an attempt to answer the first four operations, but he gave correct answers to other questions and obtained a grade 6 .

Considering and making an exception of the introduction of terms such as square roots and number powers, we supposed that other numeric expressions such as whole numbers, fractions and products, has already been learned when they were in elementary school. However, they were, in fact, learning these concepts for the first time. Can we consider that the students forgot the knowledge because they didn't practice it? This occurs in the case of fractions, which are not taught or used beyond elementary school $[4,8,23]$. We also observed deficiencies on this. Definitely, supplying temporary help is not a proper remedial education strategy, it can fosters a delusion and the complacency teacher. The only consistently successful strategy was intensive re-teaching, when no polynomial drills were practiced during performance. This exposure gave participating students both a descriptive and a recreational orientation, and encouraged them to look for connections between Spanish (the language of the test), and mathematics.

\section{RIGHT ANSWERS IN THE TREATMENT}
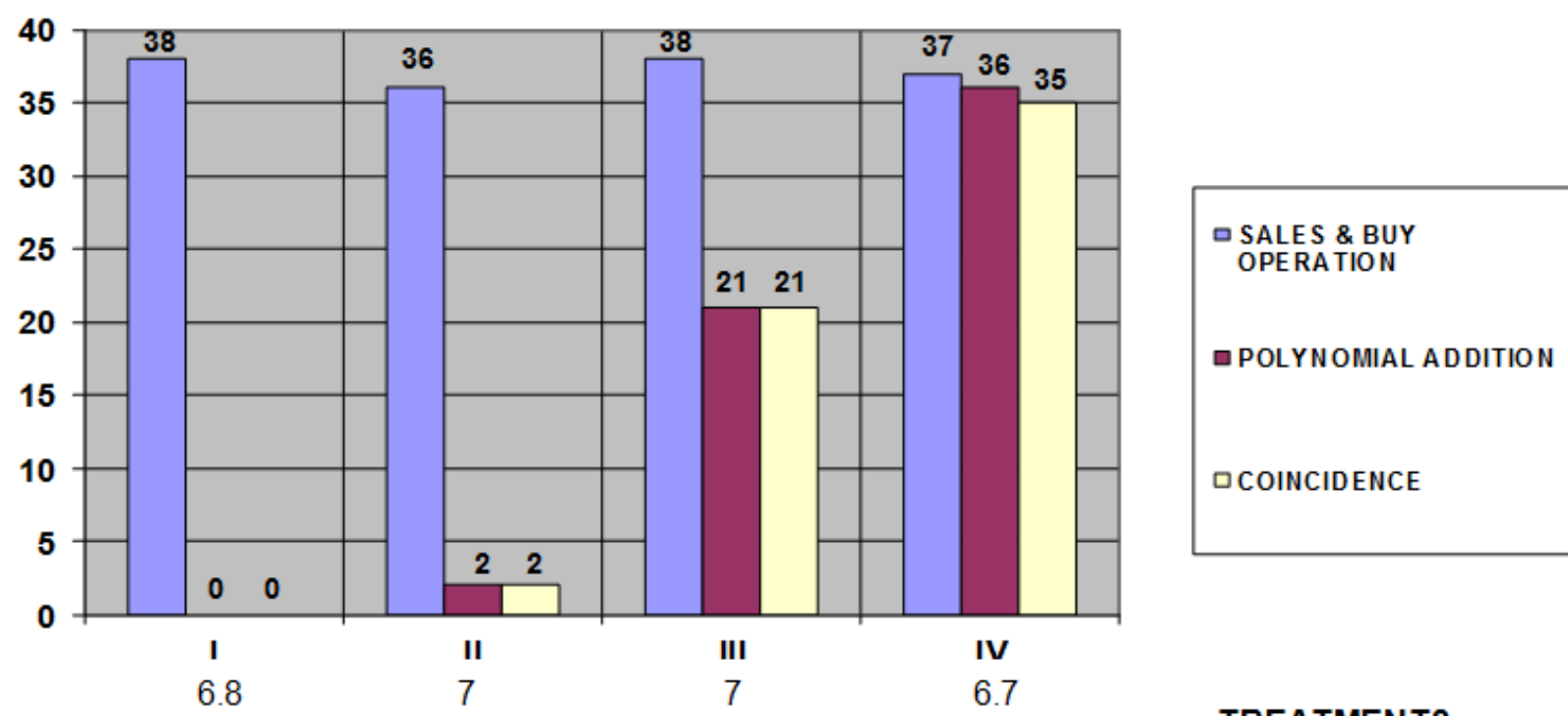

\section{TREATMENTS}

\section{GRADE IN THE CONTEXTUAL MATHEMATICAL QUESTIONNARE}

Figure 1. Results of the four treatments applied.

\section{TREATMENTS:}

I. Without intervention

II. Casual information intervention

III. Ad hoc assistance for students

IV. Intensive and formal class

We should mention that this group was not the most brilliant at the shop bargaining. It is evident that group IV advanced most in polynomial-solving, though it was not the group that obtained the best grade in the contextual mathematical questionnaire. In this group, one student gave the right answer to the polynomial problem and obtained a grade 10 in the contextual questionnaire, even though it was wrong in the buy-and-sell bargaining. This was thought to be a lapsus numerae (accidental mistake while making a mathematical operation).

In other instances of this experience, we have observed variations in the order of $+/-2$ points in relevant score (specially, with polynomial addition), for this same case study with all four remediation strategies described, here including the 'control'. This estimate cannot be projected to other topics of learning, with minor difficulty index $(\mathrm{X} / \mathrm{N}$; 
in higher ratios is near to 1 , that is more easy subjects), of the example we report.

\section{Collaborative Assessment}

In an independent session, we discussed the results of the complete questionnaire of 12 questions with the students (in their groups). We gave a detailed explanation of the polynomial in each treatment. A conclusion was reached - the real problem of learning mathematics is not always well explained and it was little practiced. Teachers that took part and whose cooperation we appreciate also agreed with this last observation. Math implies the need to know how to move toward the kind of mathematical understanding needed in order to teach mathematics well $[12,19]$.

Students and teachers generally understood that this methodological approach focuses on micro evaluation (where details are analyzed) and micro-teaching (regarding specific topics). In this way, it would be possible to locate within the set of subjects those thematic aspects giving rise to greater learning difficulties, so that appropriate strategies can be developed to improve teaching or correct / review at least the problematic elements (a rough estimate might be 50 topics for every field of teaching).

\section{Integral Educational Planning}

This pedagogical dynamic has several concepts often used in constructivism (materialistic theory that seeks to explain the learning considering the individual and social environment), which are supported by problem solving [6]. Two of them are described herein; cognitive transfer or $\mathrm{T}$ (the transfer of knowledge or skill possessed by the subject to solve on their own a problem to another purpose or related problem, but more complex) and zone of proximal development or ZDP (when the own ability is not enough to independently solve the problem and that it requires guidance or assistance provided by the use of various means; either directly or indirectly a facilitator or an expert) [21].

Sporadic or isolated educational intervention (whether 'normal' or remedial) is mostly inefficient or has very poor outcomes. See what was reported by students in group II who supplied correct answers. This is an evident truth or axiom confirmed by those involved in day-to-day education. What can determine success in an educational intervention to improve or remedy learning? Effective planning and organization, discipline and certainty, (above all, creativity and innovation) ensure the achievement of expected learning. All of this is possible with the proper basis. In the case of low-difficulty questions like the lollypops and chocolate purchase, or the polynomial addition corresponding to treatment IV (dis-centered items that look towards high scores), application of the alfa Cronbach coefficient is inadequate. A set of alphanumerical questions requires another kind of indicator of statistical reliability. They may not necessarily be well balanced questionnaires. This subject surely needs a more profound discussion $[25,26]$.
Agreements on international cooperation must be strengthened. Experts in every field of knowledge must be invited in order to adjust the PISA (Programme on International Students Assessment) and the PIAAC (Programme for the International Assessment of Adult Competencies) evaluation instruments, so that what is being assessed is a true world educational standard [15, 17]. So that chosen items are the measurement of skills oriented to solving real-life problems, where answers can be personalized (similar correct answers whose themes are not numerically precise) and interactivity between answers to several different questions [19]. For example, in examining the Pythagorean Theorem using a cut-short equation so that the following expression, $a^{2}-b^{2}=$ shall meet the theorem's basic principle. There will be people who cross the (-) sign to convert it to an addition $(+)$ and they will add a resulting " $c$ ", There will be others who will add a resulting " $c$ " "without touching the subtraction. In the first case, the hypotenuse is side "c" and in the second case it is side "a" that the examined student will be required to draw. In this case, the right answer will be calculated according to the correspondence between the answers to related questions [22]. The new examination format, though undoubtedly more complex, does, however, have more right-answer options and will tend in the short term to bias current tests towards a greater relative difficulty, but will also lead to a long term improvement in world basic education. Will current PISA leaders such as China, Singapur and Korea not also be able to improve their educational systems?

\section{References}

[1] Alatorre S: Aspectos temáticos del efecto remanente de las matemáticas en México. In: Algunos problemas de la educación en matemáticas en México, A. De la Peña (compiler), México. D.F., Siglo xxi Editores, 2002: 51-112

[2] Alatorre S: Numeralismo: un asunto que incumbe a todo el mundo (Sí, también a usted a quien las matemáticas lo aturden), Revista Mexicana de Investigación Educativa, 2011, 16(50):961-986. Available at: http://redalyc.uaemex.mx/redalyc/pdf/140/14019000013.pdf

[3] Backhoff EE, Andrade ME, Peon ZM, Bouzas RA, Santos RA, Martínez RF (collaborator): El aprendizaje del español y las matemáticas en la educación básica en México. Sexto de primaria y tercero de secundaria, Instituto Nacional para la Evaluación de la Educación (inee), México, D. F, 2006.

[4] Berry RB, Bol L, McKinney SE. Addressing the principles for school mathematics: a case study of elementary teachers' pedagogy and practices in an urban high-poverty school. International Electronic Journal of Mathematics Education, 2009, 4(1):1-22.

[5] Elizondo A, Paredes F, Prieto A: Enciclomedia: un programa a debate, Revista Mexicana de Investigación Educativa, 2006, 11(28):209-224. Available at: http://redalyc.uaemex.mx/src/inicio/ArtPdfRed.jsp?iCve=140 02811 
[6] Flavell J.H: Theory of mind development: retrospect and prospect. Journal of Developmental Psychology, 2004, 50(3):274-290.

[7] García AM, Benítez YR, Huerta EV, Ruiz GC: Infraestructura escolar en las primarias y secundarias de México, Instituto Nacional para la Evaluación de la Educación (inee), México, D.F, 2007.

[8] Hart K: Children's understanding of mathematics: 11-16, John Murray (Publishers), London, 1981.

[9] Hoyles C, Noss R: Improving Mathematics at Work: The Need for Techno-mathematical Literacies, Oxon: Routledge, 2010 .

[10] INEE. Panorama educativo de México. Indicadores del Sistema Educativo Nacional. México, 2012.

[11] Lave J: Cognition in practice: Mind, mathematics, and culture in everyday life. Cambridge, UK: Cambridge University Press, 1998.

[12] Loewenberg BD. The Mathematical Understandings That Prospective Teachers Bring to Teacher Education, 1990, 90(4): 449-466 Available at: http://www.jstor.org/stable/1001941?seq=1\#page_scan_tab_co ntents

[13] Nunes T, Carraher DW, Schliemann AD: Street mathematics and school mathematics, Cambridge, UK: Cambridge University Press, 1993.

[14] OECD. Education at a glance, Organization for Economic Cooperation and Development, Paris, 2001.

[15] OECD (2009a). PISA 2000, 2003, 2006, 2009. Available at: http://www.pisa.oecd.org/document/25/0.3343.en_32252351 32235731_39733465_1_1_1_1.00.html (accessed on July 12th, 2012).

[16] OECD. PISA 2012 Results in focus: What 15-year-olds know and what they can do with what they know. Available at: http://www.oecd.org/pisa/keyfindings/pisa-2012-resultsoverview.pdf (accessed on January 25th, 2015).

[17] OECD: Programme for the International Assessment of Adult Competencies (PIAAC), 2009b. Available at: http://www.oedc.org/dataoedc/13/45/41690983.pef
[18] OECD. Programa para la evaluación de alumnos (PISA) PISA 2012 - Resultados: México, 2012. Available at: http://www.oecd.org/pisa/keyfindings/PISA-2012-resultsmexico-ESP.pdf

[19] Principles and standards for school mathematics, National Council of Teachers of Mathematics, Reston (VA), 2000. Available at: http://www.nctm.org/uploadedFiles/Standards_and_Positions/ PSSM_ExecutiveSummary.pdf

[20] Robinson N, Abbott RD, Berninger VW, Busse J, Mukhopadhyay S: Developmental changes in mathematically precocious young children: longitudinal and gender effects. Gifted Child Quarterly, 1997, 41(4):145-158.

[21] Ruiz HC. Hacia una comprobación experimental de la zona de desarrollo próximo de Vigotsky. Ciencia ergo-sum Revista Científica Multidisciplinaria de Prospectiva, Universidad Autónoma del Estado de México, 2015, 22(2):162-166.

[22] Ruiz HC, Lupercio LA, Rodríguez SE: Comprensión lectora de un examen con dos estrategias propedéuticas en estudiantes universitarios. Revista Intercontinental de Psicología y Educación, 2009, 11(2):79-90. Available at: http://redalyc.uaemex.mx/pdf/802/80212414005.pdf

[23] Rychen DS, Salganic LH: Key competencies for a successful life and a well-functioning society, Gottingen, Germany: Hogrefe \& Huber, 2003.

[24] Tardif M. Elementary and Secondary School Teachers vis-àvis Knowledge: Some Socio historical Considerations about the Problem of Teaching Knowledge. Science Journal of Education, 2013, 1(5):104-117. Available at: http://article.sciencepublishinggroup.com/pdf/10.11648.j.sjedu .20130105.18.pdf

[25] UNESCO: The plurality of literacy and its implications for policies and programmes, 2009. Available at: http://unesdoc.unesco.org/images/0013/001362/136246e.pdf

[26] Van den Heuvel-Panhuizen M, Gravemeijer KPE: Tests are not all that bad: An attempt to change the appearance of written tests in mathematics instruction at the primary school level, in Streefl and, L. (Ed.), Realistic mathematics education in primary school, Utrecht: Freudenthal Institute, 1991.

[27] Walkerdine V: Difference, cognition, and mathematics education, For the Learning of Mathematics, 1990, 10 (3): 5156. 